\title{
MNC Transactions Foreign Exchange Exposure: An Application
}

\author{
Augustine C. Arize ${ }^{1}$, Giuliana Campanelli Andreopoulos ${ }^{2}$, \\ Ioannis N. Kallianiotis ${ }^{3}$, John Malindretos ${ }^{4}$
}

\begin{abstract}
:
The main aim of this article is to investigate the foreign exchange exposure in international transactions and how it affects profitability and the market value of firms.

The present study analyses the transaction cost associated with these transactions which is part of a more extended research using a questionary sent to multinational companies included in the Forbes 500.

Results are consistent with other studies supporting the hypothesis that foreign exposure is a main problem in international business and it must be treated in a unique way by IAS.
\end{abstract}

Keywords: Multinational transactions, foreign exchange exposure, hedging.

\footnotetext{
${ }^{1}$ Regents Professor, Department of Economics and Finance College of Business, Texas A\&M University

${ }^{2}$ Department of Economics and Finance, Cotsakos College of Business, William Paterson University

${ }^{3}$ Department of Economics and Finance, Arthur Kania School of Management, University of Scranton

${ }^{4}$ Department of Economics, Finance and Global Business, Cotsakos College of Business, William Paterson University, jnmalindre@optonline.net
} 


\section{Introduction}

Foreign exchange exposure is a measure of a firm's profitability, net cash flow, and market value changing as a result of a change in exchange rates. An important duty of the financial manager is to measure the effect of foreign exchange exposure and manage it in such a way as to maximize the profitability, net cash flow and market value of the firm. When foreign exchange rates change, the effects on a firm can be measured in several ways. In this study, we shall examine the transactions kind of foreign exchange exposure and the hedging of that exposure by US multinational enterprises.

The first half of this paper will analyze the theory of the transactions form of foreign exchange exposure. The second half of the paper will include a survey sent to over two hundred multinational companies which were listed in the Forbes 500 top multinational companies. This portion of the paper will include a copy of the survey itself, the cover letter that explained to the companies CFO what the purpose of our survey was, and an explanation of our observations from the responses sent back to us.

\section{Transactions Exposure}

Transaction exposure refers to gains or losses that can occur from the settlement of transactions whose terms are stated in foreign currencies. Transactions may include borrowing or lending funds denominated in foreign currencies, acquiring assets or incurring liabilities denominated in foreign currencies, purchasing or selling on credit goods or services the prices of which are stated in foreign currencies, or being a party to an unperformed forward foreign exchange contract. Transaction exposure is measured by both currency and affiliate companies as well.

As a practical example of transaction exposure, if a multinational company has a receivable or payable denominated in a foreign currency and expects the foreign exchange rate to be at a certain number relative to the home currency on the payment date (paid out or received in), the transaction exposure would be the risk that the exchange rate will be different from that which was expected on the payment date.

So if a United States based company sold goods on an open account to a Nigerian buyer for $400,000 \mathrm{~N}$, payment to be made in 30 days, and the United States based company expects to exchange the $400,000 \mathrm{~N}$ for 10,000 dollars (exchange rate of $40 \mathrm{~N} /$ USS) when payment is received, exposure will occur because of the risk that the U.S. firm will receive something other than 10,000 dollars after the Nairas are exchanged for dollars. If the exchange rate would end up at $42 \mathrm{~N}$ per U.S. dollar, then the U.S. seller would receive only 9,524 dollars, which is 426 dollars less than anticipated. It is important to note that had the United States seller accepted 
payment only in dollars, than the transaction exposure would have shifted to the Nigerian buyer.

Another example of transaction exposure arises when money is borrowed or loaned out and the amount involved is denominated in a foreign currency. So if a U.S. firm borrows 100 million $\mathrm{N}$ from a Nigerian bank at a time when 100 million $\mathrm{N}$ are worth 10.13 million dollars, and five years later the loan is due with the cost of repayment of the principle at 22.32 million dollars, the U.S. company will have suffered a large transaction loss.

In general, transaction exposure will arise partly from accounts receivable, all other monetary receivables, and all monetary debt. In addition to the exposed balance sheet items, there are four off-balance sheet items that create transaction exposure.

1. Unfilled customer orders at fixed foreign currency prices: They are accounts receivables which are not yet recorded on the affiliate companies books and when denominated in a foreign currency, they set up a fixed amount of such currency to be received at a future date, regardless of the foreign exchange rate at that time.

2. Purchase commitments at fixed foreign prices: Obligations to purchase such items as raw materials, components, physical facilities, and energy, which are denominated in a foreign currency.

3. Contracts to buy foreign exchange forward: Contracts obligating the affiliate company to deliver at some point in the future, a specific amount of its home currency and receive a predetermined amount of a foreign currency at an already established exchange rate. This creates an exposed position similar to that of an account receivable

4. Contracts to sell foreign exchange forward: The exact opposite of a contract to buy foreign exchange forward. It creates an exposed position similar to that of an account payable.

The three most common methods used to offset transaction exposure are forward market hedging, money market hedging, and options market hedging. However, many multinational companies will opt not to hedge transaction foreign exchange exposure.

When using a forward contract to hedge transaction foreign exchange exposure, the contract is entered into at the time transaction exposure is created (ex. a sale is made on an open account). Funds to fulfill the contract will be available at the future date in which the balance in the account receivable is collected and therefore the forward is said to be "covered" and the miginal sale on account is to be a "covered transaction". The firm-has therefore eliminated its foreign exchange risk relative to this transaction. 
When using a money market hedge against transaction exposure, both a contract to a loan agreement and source of funds to satisfy the loan agreement is set up. A company looks to use the money market hedge borrows in one currency and exchanges the proceeds for a different currency. Funds to satisfy the loan agreement may be generated from business operations in which the money market hedge is then considered "covered The main difference between a money market hedge and a forward exchange hedge is that the cost of a money market hedge is determined by differential interest rates, while the cost of the forward exchange market hedge is a function of the forward rate quotation.

When using the options market to hedge transaction exposure, a put option can be purchased in which the company can speculate on the upside potential for appreciation of, the foreign currency while limiting downside risk to a specific and known amount. It is also possible to buy a call option on one's own currency. Although, the cost of purchasing the option will yield a lower net amount than that of a money market hedge or a forward exchange market hedge, the upside potential with an options market hedge is much greater than that of the other two.

Foreign currency options have a variety of uses. Put options may be used by construction firms and other exporters when they need to submit a fixed price bid in a foreign cunency without knowing until some time in the future whether their bid will be successful. A put option can be used to hedge the foreign exchange risk either for just the bidding period or for the entire period of potential exposure if the bid is won. If the bid is rejected, the loss is limited to the cost of the option. As a side note, if the transaction foreign exchange risk is hedged by a forward contract and the bid is rejected, the forward contract will have to be either reversed or eventually fulfilled at an unknown potential loss or gain. The bidder would essentially have an uncovered forward contract.

\section{Analyzing the Data}

As previously indicated, a survey of two questions was e-mailed to the Chief Financial Officers of two hundred United States based Multinational Companies. The cover letter explained to them that the purpose of the survey was to see, if and how they managed their foreign exchange risk. It also explained to them that it was an academic research paper.

The firms receiving the survey were the two hundred largest Multinational Companies appearing in the Forbes 500 list. The fact that these corporations had foreign operations was verified by checking the Directory of American Firms Operating in Foreign Countries (Columbia University Business Library). The email indicated that all responses would be anonymous and confidential. A total of thirty- two usable responses were returned for a response rate of sixteen percent. The response rate for mail questionnaires is usually around twenty-five percent, but can be even lower. 
Question one asked whether or not the corporation hedged against transactions foreign exchange exposure:

1. Approximately sixty-four percent of the respondents indicated that they do in fact hedge transaction foreign exchange exposure.

Question two asked what techniques do the corporations use to hedge transaction foreign exchange exposure:

1. Approximately fourty-two percent of the companies, who do in fact hedge transaction foreign exchange exposure, do so through the use of a money market hedge.

2. All sixty-four percent $(100 \%)$ of these respondents use forward foreign exchange hedging against transaction foreign exchange exposure.

3. Approximately seventy-one of these respondents hedge transaction foreign exchange exposure through the use of currency options.

4. Approximately fifteen percent of these respondents hedge transaction foreign exchange exposure through the diversification of operations.

5. Approximately twenty-nine percent these respondents hedge transaction foreign exchange exposure through the diversification of financing.

6. Approximately fifteen percent of these respondents hedge transaction foreign exchange exposure through the diversification of sales.

7. Approximately twenty-nine percent of these respondents hedge transaction foreign exchange exposure through the diversification of sourcing.

8. No Futures hedging was reportedly used by any of the responding companies to hedge against transaction foreign exchange exposure.

\section{Conclusion}

This study provides evidence on translation, transaction, and economic foreign exchange exposures. From these responses, it is possible to make several conclusions regarding the foreigh exchange risk associated in interrnational transactions.

This is consistent with previous studies, which have indicated that the majority of firms seem to have a better understanding of transaction foreign exchange exposure. In addition, those same studies indicated that coverage against translation exposure continue to rise relative to the shift to FAS \#52. 


\section{References:}

Aggarwal, R. Harper, J.T. 2010. Foreign Exchange Exposure of "Domestic"

Corporations. Journal of International Money and Finance, 29(8), 1619-1636.

Ahmed, L. 2015. The Effect of Foreign Exchange Exposure on the Financial Performance of

Commercial Banks in Kenya. International Journal of Scientific and Research

Publications, 5(11), 115-120.

Alssayah, A., Krishnamurti, C. 2013. Theoretical Framework of Foreign Exchange Exposure, Competition, and the Market Value of Domestic Corporations. International Journal of Economics and Finance, 5(2), 1-14.

Ampomah, S.A., Mazouz, K., Yin, S. 2013. The Foreign Exchange Exposure of UK NonFinancial Firms: A Comparison of Market-Based Methodologies. International Review of Financial Analysis, 29, 251-260.

Andersen, L.S., Fischer, D.A. 2012. Foreign Exchange Exposure: The Relationship Between Multinationality and Financial Hedging. Aarhus University Business and Social Sciences.

Aysun, U., Guldi, M. 2011. Exchange Rate Exposure: A Nonparametric Approach. Emerging Markets Review, 12(4), 321-337.

Bae, S.C., Kwon, T.H., Li, M. 2008. Foreign Exchange Rate Exposure and Risk Premium in International Investments: Evidence from American Depository Receipts. Journal of Multinational Financial Management, 18(2), 165-179.

Bartram, S.M. 2008. What Lies Beneath: Foreign Exchange Rate Exposure, Hedging and Cash Flows. Journal of Banking and Finance, 32(8), 1508-1521.

Bartram, S.M., Brown, G.W., Minton, B.A. 2010. Resolving the Exposure Puzzle: The Many Facets of Exchange Rate Exposure. Journal of Financial Economics, 95(2), 148-173.

Chaieb, I., Mazzotta, S. 2013. Unconditional and Conditional Exchange Rate

Exposure. Journal of International Money and Finance, 32, 781-808.

Chang, C. 2009. To Hedge or Not to Hedge. Cornell University, 50(3), 301-313.

Chang, F.Y., Hsin, C.W., Shiah-Hou, S. 2013. A Re-Examination of Exposure to Exchange

Rate Risk: The Impact of Earnings Management and Currency Derivative Usage. Journal of Banking and Finance, 37(8), 3243-3257.

Chue, T.K., Cook, D. 2008. Emerging Market Exchange Rate Exposure. Journal of Banking and Finance, 32(7), 1349-1362.

Entorf, H., Moebert, J., Sonderhof, K. 2011. The Foreign Exchange Rate Exposure of Nations. Open Economics Review, 22(2), 339-353.

Fornes, G., Cardoza, G. 2009. Foreign Exchange Exposure in Emerging Markets: A Study of Spanish Companies in Latin America. International Journal of Emerging Markets, 4(1), 6-25.

Frankel, J.A., Galli, G., Giovannini, A. 2009. The Microstructure of Foreign Exchange Markets. Chicago, University of Chicago Press.

Gande, A., Schenzler, C., Senbet, L.W. 2009. Valuation Effects of Global Diversification. Journal of International Business Studies, 40(9), 1515-1532.

Huffman, S.P., Makar, S.D., Beyer, S.B. 2010. A Three-Factor Model Investigation of Foreign Exchange-Rate Exposure. Global Finance Journal, 21(1), 1-12.

Hutson, E., Laing, E. 2014. Foreign Exchange Exposure and Multinationality. Journal of Banking and Finance, 43, 97-113.

Jacque, L.L. 2013. Management and Control of Foreign Exchange Risk. Norwell, Kluwer Academic.

Krishna, M.K., Rivera-Solis, L.E., Malindretos, J. 2001. MNC Foreign Exchange Exposure 
Under FASB No. 8 and FASB No. 52: A Survey. American Business Review, XIX(1), 18-25.

Kolari, J.W., Moorman, T.C., Sorescu, S.M. 2008. Foreign Exchange Risk and the CrossSection of Stock Returns. Journal of International Money and Finance, 27(7), 10741097.

Lane, P.R. 2010. Financial Exchange Rates and International Currency Exposures. American Economic Review,100(1), 518-540.

Lee, S.K., Jang, S. 2011. Foreign Exchange Exposure of US Tourism-Related Firms. Tourism Management, 32(4), 934-948.

MacLean, R. 2009. The Six Mistakes Executives Make in Risk Management.

Makar, S.D., Huffman, S.P. 2008. UK Multinationals' Effective Use of Financial CurrencyHedge Techniques: Estimating and Explaining Foreign Exchange Exposure Using Bilateral Exchange Rates. Journal of International Financial Management \& Acounting.

Malindretos, J., Tsanacas, D. 1995. Hedging Preferences and Foreign Exchange Exposure Management. Multinational Business Review, III(2), 56-67.

Malindretos, J., Krishna, M.K., and Luis Edouardo Rivera Solis, L.E. 2015. Financial Accounting Statements and Foreign Exchange Risk Management, in Managerial Finance in the Corporate Economy, Editors D.K. Ghosh and S. Khaksari, Routledge, Chapter 21, 371-386.

Malindretos, J., Norton, E., Tsanacas, D. 1993. Hedging Considerations Under FAS \#52. The Mid-Atlantic Journal of Business, 29, 199-212.

Mudugo, E.E., Venkatraman, S. 2013. Managing Foreign Exchange Exposure: Information System Integration. Northern Melbourne Institute of TAFE.

Muller, A., Verschoor, W.F. 2008. The Latin American Exchange Exposure of U.S. Multinationals. Journal of Multinational Financial Management, 18(2), 112-130.

Naylor, M.J., Greenwood, R.C. 2008. The Characteristics of Foreign Exchange Hedging: A Comparative Analysis. Journal of Asia-Pacific Business, 9(2), 121-152.

Shboul, M.A., Allison, S.2009). The Effects of the Use of Corporate Derivatives on the Foreign Exchange Rate Exposure. Journal of Accounting-Business \& Management, 16(1), 72-92.

Thalassinos, I.E., Pintea, M., Raţiu, I.P. 2015. The Recent Financial Crisis and Its Impact on the Performance Indicators of Selected Countries during the Crisis Period: A Reply. International Journal of Economics and Business Administration, 3(1), 3-20.

Thalassinos, I.E., Stamatopoulos, D.T. and Thalassinos, E.P. 2015. The European Sovereign Debt Crisis and the Role of Credit Swaps. Chapter book in The WSPC Handbook of Futures Markets (eds) W. T. Ziemba and A.G. Malliaris, in memory of Late Milton Miller (Nobel 1990) World Scientific Handbook in Financial Economic Series Vol. 5, Chapter 20, pp. 605-639, ISBN: 978-981-4566-91-9, (doi: 10.1142/9789814566926_0020).

Thalassinos, I.E., Deceanu, L. and Pintea, M. 2010. New Dimensions of Country Risk in the Context of the Current Crisis: A Case Study for Romania and Greece. European Research Studies Journal, 13(3), 225-236. 